Revista Brasil. Bot., V.30, n.4, p.623-639, out.-dez. 2007

\title{
Species composition and biogeographic relations of the rock outcrop flora on the high plateau of Itatiaia, SE-Brazil
}

\author{
KÁTIA TORRES RIBEIRO ${ }^{1,2,3}$, BRANCA MARIA OPAZO MEDINA ${ }^{1}$ and FABIO RUBIO SCARANO ${ }^{1}$
}

(received: March 18, 2005; accepted: September 18, 2007)

\begin{abstract}
Species composition and biogeographic relations of the rock outcrop flora on the high plateau of Itatiaia, SE-Brazil). We studied the flora of vegetation islands on rock outcrops on the Itatiaia Plateau ( $22^{\circ} 21^{\prime} \mathrm{S}$ and $\left.44^{\circ} 40^{\prime} \mathrm{W}\right)$, at 2,400 m.a.s.l. A total of 114 vascular plant species, which correspond to ca. 20\%-25\% of the currently inventoried flora of the plateau, were sampled in 197 small vegetation islands (total area of 0.034 ha). Xerophytes and hydrophytes were often found side by side due to environmental heterogeneity at a small scale, explaining in part the high species diversity. Rock outcrops may support floras quite distinct from those in neighbouring habitats, due to the action of strong environmental filters, but in Itatiaia the geographic distribution patterns among rupicolous plants appear to mimic those described for the whole flora around it, with $15.1 \%$ of narrow endemic species and six strictly rupicolous plants. Underlining the "temperate" nature of the high elevation climate in Itatiaia, the sampled flora was dominated by species of the families Asteraceae and Poaceae, and the number of CAM (crassulacean acid metabolism) species was very low. A few endemic species of tropical origin - Pleurostima gounelleana (Beauv.) Men. (Velloziaceae) and Fernseea itatiaiae (Wawra) Baker (Bromeliaceae) play a crucial role in this vegetation, as pioneer mat-formers facilitating later establishment of numerous other species. Hemicryptophytes prevail in the sampled flora, while therophytes are exceptionally rare and mainly consist of opportunistic species associated with disturbances. Numerous microhabitats and strong environmental gradients in these high elevation rock outcrops afford opportunities for establishment of a highly diversified flora. These island-like environments may represent an important refuge for grassland species from fire and other disturbances in the surrounding grasslands.
\end{abstract}

Key words - Atlantic rain forest, biogeography, "campos de altitude", endemisms, rock outcrops, rupicolous plants

RESUMO - (Composição de espécies e relações biogeográficas da flora sobre afloramentos rochosos no Planalto do Itatiaia, SE do Brasil). O objeto deste estudo foi a flora que se distribui em ilhas de vegetação isoladas sobre a superfície rochosa, no Planalto do Itatiaia ( $22^{\circ} 21^{\prime} \mathrm{S}$ e $\left.44^{\circ} 40^{\prime} \mathrm{W}\right)$, a $2.400 \mathrm{~m}$ de altitude. Foi encontrado um total de 114 espécies vasculares, correspondendo a ca. 20\%-25\% da flora total atualmente inventariada do Planalto, em 197 pequenas ilhas de vegetação (área total de 0,034 ha). Xerófitas e hidrófitas com freqüência ocorrem lado a lado devido à forte heterogeneidade ambiental em pequena escala espacial, explicando em parte a alta diversidade local. Superfícies rochosas podem abrigar floras muito distintas do entorno em função de fortes filtros ambientais contrastantes, mas no Itatiaia os padrões de distribuição geográfica de plantas rupícolas assemelham-se aos dos campos no entorno, com 15,1\% das espécies sendo endêmicas restritas e seis sendo estritamente rupícolas. Destacando a natureza "temperada" do clima de altitude do Itatiaia, a flora estudada foi dominada por espécies de Asteraceae e Poaceae, e o número de espécies CAM (metabolismo ácido das crassuláceas) foi muito baixo. Algumas endêmicas restritas de origem tropical - Pleurostima gounelleana (Beauv.) Men. (Velloziaceae) e Fernseea itatiaiae (Wawra) Baker (Bromeliaceae) - formam tapetes sobre a rocha e são fundamentais para o estabelecimento de ampla gama de espécies. Hemicriptófitas predominam na flora amostrada, enquanto terófitas são excepcionalmente raras e consistem, principalmente, de espécies oportunistas associadas com distúrbio. Os numerosos microhábitats e os marcantes gradientes ambientais nestes afloramentos de altitude elevada criam oportunidades para o estabelecimento de uma flora muito diversificada. Estes ambientes insulares parecem constituir importante refúgio para as espécies dos campos em geral, frente a perturbações como incêndios e outras ações antrópicas.

Palavras-chave - afloramentos rochosos, biogeografia, campos de altitude, endemismos, Floresta Pluvial Atlântica, plantas rupícolas

\section{Introduction}

Despite their ubiquity, plant communities on rock outcrops have rarely been included in floristic inventories.

1. Universidade Federal do Rio de Janeiro, CCS, IB, Departamento de Ecologia, Caixa Postal 68020, 21941-970 Rio de Janeiro, RJ, Brazil.

2. Present address: IBAMA, Parque Nacional da Serra do Cipó, Rodovia MG-010, Km 97, Serra do Cipó, 35847-000 Santana do Riacho, MG, Brazil

3._Corresponding author: ktorres@uai.com.br
This is in part due to the difficulties of access imposed by rocky surfaces, to low economic interest, and possibly to an expectation of low diversity. Partly for these same reasons, rocky sites remain some of the better preserved terrestrial habitats on the planet, protected from grazing, fire and many other economic activities (Debrot \& Freitas 1993, Fulls et al. 1993, Larson et al. 2000). From the scientific viewpoint, these habitats are an open avenue for a lot of questions yet underexplored, from ecophysiology (Lüttge 1997, Meirelles et al. 1997) to 
phytosociology (Alves 2000), ecology (Houle \& Phillips 1989, Meirelles 1996), evolution (Benzing 2000, Seine et al. 2000), floristics and biogeography (Porembski et al. 1998, Seine et al. 2000), conservation (Burke 2002a) and the relationships with surrounding habitats (Burke 2002b, Scarano 2002).

Rocky habitats are inserted within most terrestrial biomes, and their heterogeneity is related to topographic and vegetation patchiness. The floristic composition of vegetation on rock outcrops may vary according to: (1) characteristics of the rock where they grow, such as chemical properties and composition; (2) patterns of erosion and fracturing pattern that are in turn related to rock composition (ultramafic rocks, quartzites, granites, limestones, sandstones) and local environmental conditions; (3) topographic and microclimatic variations; and (4) regional floristic context, paleoclimate and history (Porembski et al. 1994, Escudero 1996, Larson et al. 2000, Seine et al. 2000, Burke 2002a, b). Generally, diversity and vegetation cover on rock outcrops tend to increase according to humidity, rock stability and availability of places for seed germination (Larson et al. 2000), but endemism may be more related to degree of isolation of the rock outcrop in relation to similar habitats and also to how intensely the ecological conditions on the rock surface represent a barrier for establishment of plants from the surrounding (also called 'matrix') vegetation (Larson et al. 2000, Burke 2002a, b).

Rock surfaces constitute an ecological barrier to the majority of plant species in surrounding matrix vegetation due to a combination of factors such as low water retention, scarcity of nutrients, difficulties of seed retention and germination, and increased exposure to winds and insolation relative to neighbouring areas (Larson et al. 2000). Thus, rock outcrops frequently support a very specialized vegetation (Sarthou \& Villiers 1998, Booth \& Larson 1999, Burke 2002a). Some plant groups show clear specialization or pre-adaptations for survival in these environments, such as in the case of the resurrection plants, which are capable of rehydrating desiccated leaves (in South America, mainly Cyperaceae and Velloziaceae; Meirelles et al. 1997), as well as other adaptive characteristics for dry and otherwise poor habitats (e.g., tank-forming leaves, bulbs, and atmospheric roots) common to pioneer species from many families Orchidaceae, Bromeliaceae, Velloziaceae, Cyperaceae, Cactaceae. Some of these plants, mainly the monocots, spread on the rock surface forming vegetation mats where other plants may grow, in a clear facilitation mechanism (Porembski et al. 1998, Scarano 2002, Medina et al. 2006).
We focused on the vegetation growing on rock outcrops at the high elevation grasslands on the Itatiaia Plateau, inserted in the Atlantic rain forest domain (Scarano 2002). These grasslands, or "campos de altitude", occur above 2,000 $\mathrm{m}$ a.s.l., along the mountain chains of southeastern Brazil. Montane environments are often spatially heterogeneous (Monasterio \& Vuillemier 1986, Safford 1999a), and those in southeastern Brazil have dwarf forests, montane bamboo, marshes, humid slopes and rock outcrops, and each of these habitats has its own physiognomy and floristic composition (Brade 1956). These habitats are all exposed to temperatures below 0 ${ }^{\circ} \mathrm{C}$ on many winter nights, however each has a distinct set of limiting conditions, involving such factors as wind intensity, light radiation, UV and nutrient scarcity (Segadas-Vianna \& Dau 1965, Rizzini 1979, Safford 1999a, Scarano et al. 2001). On rock outcrops, however, limiting abiotic conditions are extreme due to plant exposure and absence of soil, causing low water retention and low nutrient availability, as well as reduced buffering of environmental fluctuations (Meirelles et al. 1997, Larson et al. 2000).

We report on the floristic composition of rupicolous vegetation of the Itatiaia Plateau, and present data about biogeographic relations, life-form distribution and association with different micro-habitats. We also discuss the implications of variation in area of vegetation islands, investigating in details the general trends outlined by Safford \& Martinelli (2000) for the rock outcrop vegetation in elevated places, in southeastern Brazil.

\section{Material and methods}

Study site - The Itatiaia Plateau ( $22^{\circ} 21^{\prime} \mathrm{S}$ and $\left.44^{\circ} 40^{\prime} \mathrm{W}\right)$ is located at the central portion of the "Serra da Mantiqueira", which runs parallel to "Serra do Mar" and to the southeastern and southern Brazilian coast. The grasslands occur above 2,000 $\mathrm{m}$ a.s.1., above the cloud forest belt (Brade 1956). The study site is within the limits of the "Parque Nacional do Itatiaia". Many other high altitude grasslands are found on mountain peaks in the "Serra da Mantiqueira" and "Serra do Mar", totalling ca. $350 \mathrm{~km}^{2}$ (Safford 1999a). The climate is mesothermic, markedly seasonal, with cold and dry winters and very wet summers. Mean annual temperature is about $14{ }^{\circ} \mathrm{C}$ and lower temperatures sometimes fall below $-10{ }^{\circ} \mathrm{C}$ among the ca. 56 nights of freezing temperatures per year. Annual rainfall is ca. 2,400 mm, concentrated in the summer months. Although there is no clear lack of rainfall during the winter, the reduced cloudiness and the high evaporation rates (mean about 90 mm in August; Segadas-Vianna \& Dau 1965) in this season result in strong desiccation of the vegetation, specially on shallow soils. 
Above 2,000 $\mathrm{m}$ a.s.1., the plateau has an area of ca. 50 $\mathrm{km}^{2}$ and from 415 (Martinelli et al. 1989) to 550 (Safford 1999a) species described. The former authors claim that $11 \%$ of the total number of species are restricted endemics to high elevation habitats on the Itatiaia Plateau, and a further $21 \%$ are more widespread habitat endemics to southeast Brazilian high-elevation grasslands in general. Shrubs appear only rarely in these grasslands, and woody vegetation often forms clumps protected by boulders, which is probably related to the previous fire regime (Brade 1956, Daubenmire 1968, Safford 2001, Medina et al. 2006). A recent review of climatic and physical characteristics of Brazilian high altitudinal grasslands based on climatic data from Segadas-Vianna \& Dau (1965) is found in Safford (1999a, b). No other study focused specifically the rupicolous vegetation of Itatiaia.

In Itatiaia, the predominant rock is nepheline-syenite, an alkaline plutonic rock not very common in Brazil, where it occurs only in Poços de Caldas (state of Minas Gerais), the island of São Sebastião (state of São Paulo), and the mid-Atlantic island of Trindade, $1,167 \mathrm{~km}$ west of the state of Espírito Santo (Almeida 1961, Leinz \& Amaral 1989). Nepheline-syenite has small crystals and high dissolution rates, frequently forming channels and holes (Leinz \& Amaral 1989). However, narrow fissures, which are common in granite and allow for rooting of vascular plants, are rare. In Itatiaia, the protosoils associated with rock surfaces are extremely rich in aluminium, as discussed by Benites et al. (2003). Like heavy metals, high aluminium concentration may be avoided, tolerated or even required, as showed by Haridasan (2000) for some "cerrado" species, and may be another important causal factor in the genesis of endemisms (Major 1988).

The rupicolous vegetation is often distributed as isolated patches with relatively well delimited borders, and may be treated as vegetation islands, with the theoretical and methodological approach set by the island biogeography studies (Michelangeli 2000, Rosenzweig 1995).

Sampling - We sampled a total of $337.1 \mathrm{~m}^{2}$ of vegetation distributed in 197 islands, covering a wide range of microhabitats and topographies on rock outcrops around a tall rock formation ("tor"), known as 'Prateleiras', at approximately 2,400 m a.s.1. ( $22^{\circ} 21^{\prime} \mathrm{S}$ and $44^{\circ} 40^{\prime} \mathrm{W}$; figure 1 ). Two different habitat types were surveyed (figure 2): (a) the extensive and relatively flat rock outcrops that are completely exposed to winds ('rock shields', hereafter), and (b) boulders of 3-4 m of height accumulated at the base of the cliff ('talus slopes' hereafter, following Larson et al. 2000). The two habitat types were sampled in two sites: Site 1, at the north face of the cliff, and Site 2, at the west face.

In the rock shields of Site 1, 102 islands (total area: $159.02 \mathrm{~m}^{2}$ ) were sampled ramdomly by the point-centre quarter method, usually employed in individual sampling (Krebs 1998) but adapted here for random choice of islands. On a neighbouring talus slope, all 32 vegetation islands found on four large boulders were included in the analyses (total area:
$35.41 \mathrm{~m}^{2}$ ), totalling 134 islands, for Site 1, ranging from 0.01 to $18.10 \mathrm{~m}^{2}$, and $194,7 \mathrm{~m}^{2}$ of vegetation cover. This group of islands was monitored monthly for two years, from March 1999 to March 2001, for community dynamics description, and life-form classification. The islands from Site 2 were surveyed just once, in May 1999, when all 63 islands found there, totalling $142.4 \mathrm{~m}^{2}$ of vegetation, were measured and inventoried. From these, 33 islands $\left(87.1 \mathrm{~m}^{2}\right)$ were in a rock shield and $30\left(55.3 \mathrm{~m}^{2}\right)$ on boulders at the talus slope.

Voucher specimens were deposited in the Herbarium of the Botany Department, "Universidade Federal do Rio de Janeiro" (RFA), and duplicates are available at the institutions of the specialists who identified the material.

Vegetation islands were categorised according to an adaptation of the scheme of Seine et al. (1998): fissures, drainage canals, rock pools of flat bottom and, finally, convex surfaces. The association of species composition, topography and island area is explored elsewhere (Ribeiro 2002).

Geographic distribution - Geographic distribution of plant species was determined based on literature, whenever possible, and on herbarium data (RB, R, RFA, K). Most species were determined by specialists and the remaining identifications were based on publications of the flora of Itatiaia (mainly Brade 1956). Although aware of the many limitations of defining plant geographic distribution based on herbarium sheet - problems with synonymies, unprecise or erroneous identification (Thomas et al. 1998), etc. - we decided to analyse the whole set of species to avoid discrepancies between well $-v s$. poorly studied families.

The following geographic distribution patterns were recognised: $\mathrm{E}=$ species endemic to the "Itatiaia" Plateau; $\mathrm{SE}=$ restricted to southeastern Brazil; $\mathrm{SE}+\mathrm{S}=$ southeastern and southern Brazil; SE+NE = southeastern and northeastern Brazil; $\mathrm{B}=$ Brazil; $\mathrm{A}=$ South America or Americas; $\mathrm{C}=$ cosmopolitan. Few species also occur in Central Brazil (CB: states of Goiás, Mato Grosso and/or Mato Grosso do Sul) and/or on southern countries (ConeS: Paraguay, Uruguay and/or Argentina). $\mathrm{H}=$ restricted to mountains, irrespective of distribution, also included plants that occur in low altitude places only in high latitudes (Brazilian state of Rio Grande do Sul, Argentina, Uruguay). We also noted cases of disjunction between the Andes and southeastern Brazil at both the genus and species level (table 1).

Life form characterization - Species were classified into life-forms following the widely used scheme of Raunkiaer (1934, apud Cain 1950), allowing comparisons with other published accounts (Cain 1950, Pavón et al. 2000). The following grouped categories were used: $\mathrm{Ph}$ - phanerophytes (including the bambuses); H - hemicryptophytes, distinguishing here those with rosetted leaves (H (R)); Ch Chamaephytes (including the prostate cactus Schlumbergera microsphaerica); C - Cryptophytes (including geophytes and hydrophytes), and $\mathrm{Th}-$ Therophytes. Classification followed mainly field observations. The spectrum obtained was compared to those described by other studies about rupicolous vegetation (table 2). 

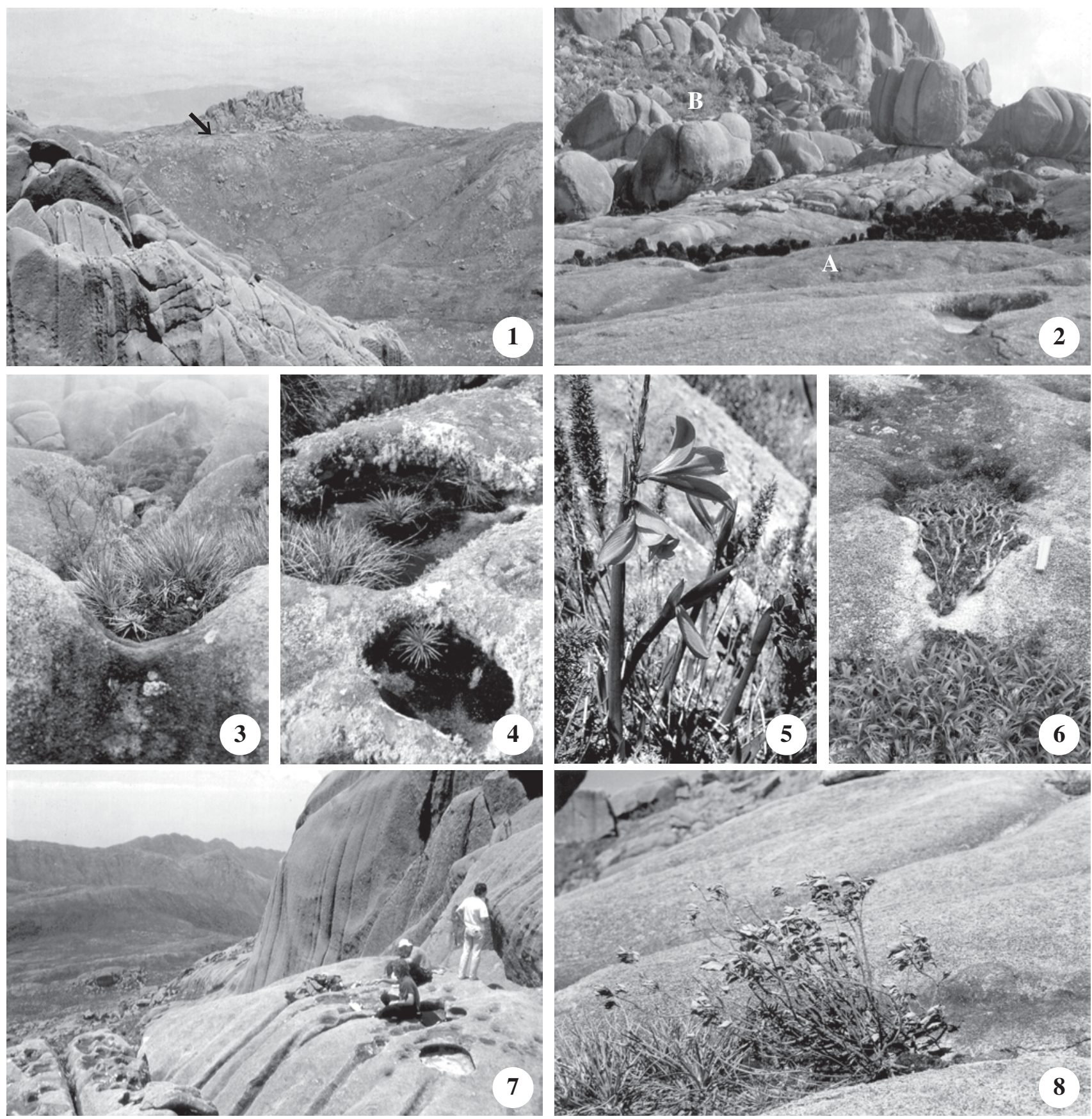

Figures 1-8. View of the Prateleiras massif from the "Pico das Agulhas Negras". 1. The arrow indicates the study area. 2. Illustration of the main habitats within the study area - A. open shield area; B. boulder on the tallus slope. 3, 4. The pioneer mat-forming hemicriptophyte Fernseea itatiaiae (Bromeliaceae) respectively in the boulder area, in a well-drained shallow depression, and within a flooded rock pool, associated to the moss Campylopus pilifer, forming horseshoe shaped islands. 5. The geophyte Hippeastrum morelianum common in all island types, associated to the endemic Chusquea microphylla, that occurs only in the open shield area. 6. An island formed basically by Pleurostima gounelleana that was in a clear splitting process, with plant parts surviving better in the shallow depressions. 7. Abundance of rock pools devoided of vascular plantas in the Agulhas Negras massif. 8. An individual of the pioneer shrub Baccharis stylosa exposed to the strong winds of September 2000 - the showed shoots were dead in the following month, with reduction in plant height due to wind action. 
Table 1. Checklist of the species sampled on rock outcrops of Itatiaia Plateau and patterns of geographic distribution: E = endemic to the Itatiaia plateau and neighbouring peaks; $\mathrm{SE}=$ occurrence across southeastern Brazil; $\mathrm{SE}+\mathrm{S}=\mathrm{Southeastern}$ and Southern Brazil; SE+NE = Southeastern and Northeastern Brazil; B = Brazil; A = South America or Americas; C = cosmopolitan. ConeS = occurring also in southern countries of South America (Argentina, Uruguay and/or Paraguay); CB = found also in states of Central Brazil (Mato Grosso do Sul, Mato Grosso and/or Goiás). R = restricted to mountain ranges whatever the distribution, including those species restricted to mountains when in the tropics, but with generalized distribution at higher latitudes (RS, Argentina, Uruguai). See text for details. The following notations were also included: Andes - Southeast Brazil disjunction at the genus level $\left({ }^{\$}\right)$, on species level ${ }^{\$}$. Life-forms: $\mathrm{G}=$ geophyte; $\mathrm{H}=$ hemicryptophyte of graminoid habit; Hros = hemicryptophyte with leaf rosette; $\mathrm{Ch}=$ chamaephyte; $\mathrm{Ph}=$ phanerophyte; $\mathrm{Th}=$ therophyte; $\mathrm{S}=$ succulent; and bambuses.

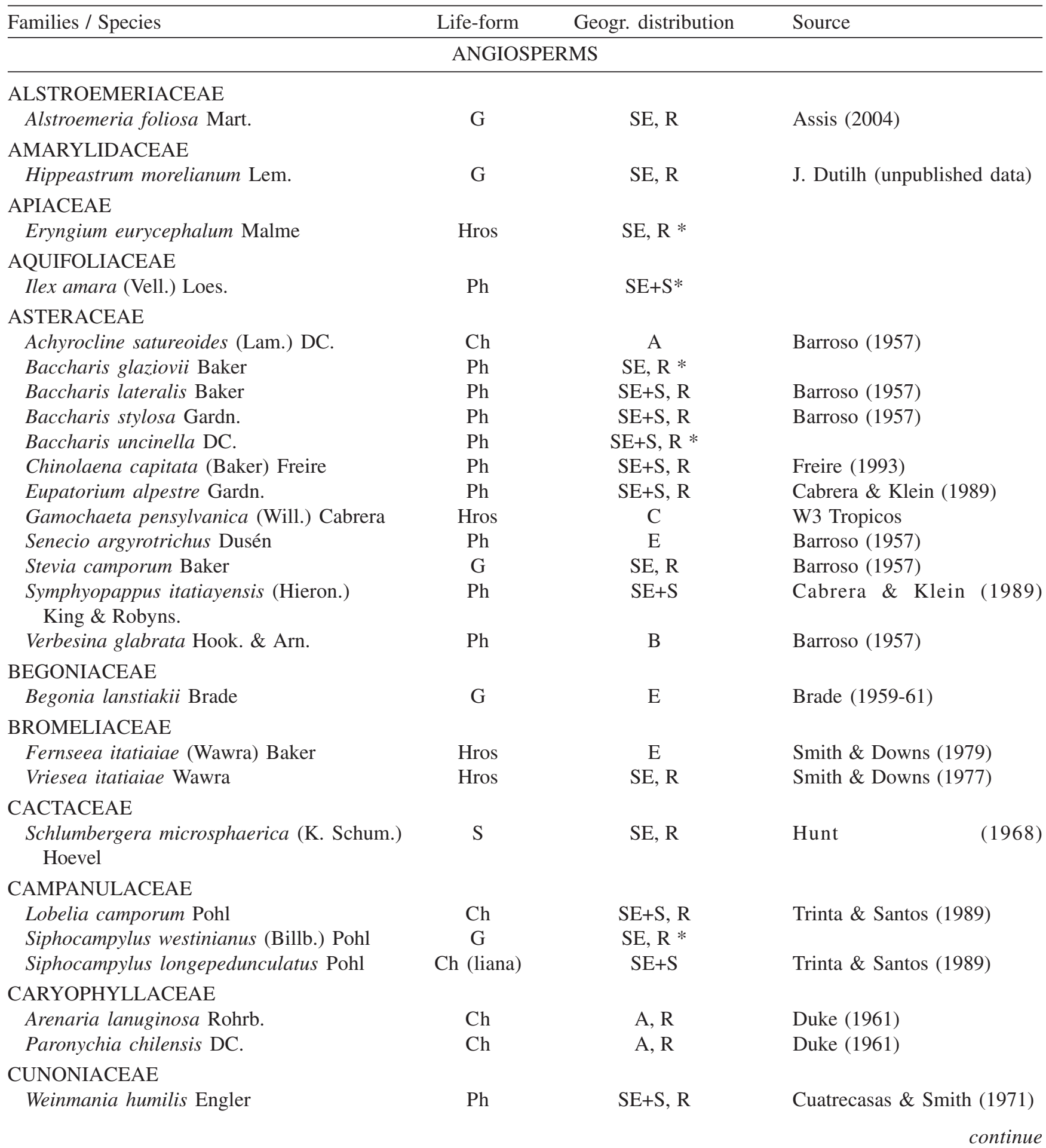


continuation

\begin{tabular}{|c|c|c|c|}
\hline Families / Species & Life-form & Geogr. distribution & Source \\
\hline \multicolumn{4}{|l|}{ CYPERACEAE } \\
\hline Rhynchospora cf. pallae Kuek. & $\mathrm{H}$ & & \\
\hline Cladium ensifolium Benth. & $\mathrm{H}$ & SE, R & Brade (1956) \\
\hline Lagenocarpus cf. triquetrus (Boeck.) Kuntze & $\mathrm{H}$ & & \\
\hline Carex aff. fuscula d'Urv. & $\mathrm{H}$ & & \\
\hline Carex sp. & $\mathrm{H}$ & & \\
\hline Cyperaceae sp. 1 & $\mathrm{H}$ & & \\
\hline \multicolumn{4}{|l|}{ DIOSCOREACEAE } \\
\hline Dioscorea perdicum Taubert & $\mathrm{G}$ & $\mathrm{SE}+\mathrm{NE}$ & G. Pedralli (unpublished data) \\
\hline Dioscorea demourae R. Knuth & G & A & G. Pedralli (unpublished data) \\
\hline \multicolumn{4}{|l|}{ ERICACEAE } \\
\hline Gaylussacia amoena Cham. & $\mathrm{Ph}$ & $\mathrm{SE}, \mathrm{R} *$ & Luteyn (1995) \\
\hline $\begin{array}{l}\text { Gaultheria serrata (Vell.) Sleumer ex K. } \\
\text { Gouvêa }\end{array}$ & $\mathrm{Ph}$ & $\mathrm{SE}+\mathrm{S}, \mathrm{R}$ & Luteyn \\
\hline \multicolumn{4}{|l|}{ ERIOCAULACEAE } \\
\hline Leiothrix argyroderma Ruhl. & Hros & E & Brade (1956) \\
\hline Leiothrix beckii (Szysz.) Ruhl. & Hros & E & Brade (1956) \\
\hline Paepalanthus itatiaiensis Ruhl. & Hros & $\mathrm{E}$ & Brade (1956) \\
\hline \multicolumn{4}{|l|}{ EUPHORBIACEAE } \\
\hline Croton migrans Casar. & $\mathrm{Ph}$ & $\mathrm{SE}+\mathrm{S}, \mathrm{R}$ & Smith et al. (1988) \\
\hline \multicolumn{4}{|l|}{ GESNERIACEAE } \\
\hline Sinningia gigantifolia Chautems & $\mathrm{Ch}$ & $\mathrm{SE}, \mathrm{R} *$ & \\
\hline \multicolumn{4}{|l|}{ IRIDACEAE } \\
\hline Sisyrinchium sp. & $\mathrm{H}$ & & \\
\hline Sphenostigma sellowiana Klatt. & $\mathrm{G}$ & SE, R & Brade (1956) \\
\hline Trimezia sp. & G & & \\
\hline Iridaceae sp. 1 & $\mathrm{H}$ & & \\
\hline \multicolumn{4}{|l|}{ JUNCACEAE } \\
\hline Juncus microcephalus Kunth & G & $\mathrm{A}, \mathrm{R}^{\$}$ & Balslev (1996) \\
\hline \multicolumn{4}{|l|}{ LAMIACEAE } \\
\hline Salvia itatiaiensis Dusén & $\mathrm{Ph}$ & $\mathrm{E}$ & Pereira (1957) \\
\hline Lepechinea speciosa (A. St.-Hil.) Epling & $\mathrm{Ph}$ & $\mathrm{SE}, \mathrm{R}\left({ }^{\$}\right)$ & Pereira (1957) \\
\hline \multicolumn{4}{|l|}{ LENTIBULARIACEAE } \\
\hline Utricularia reniformis A. St.-Hil. & $G$ & $\mathrm{SE}+\mathrm{S}, \mathrm{R}$ & Taylor (1980) \\
\hline Utricularia globulariaefolia Mart. ex Benj. & G & $\mathrm{SE}, \mathrm{R} *$ & \\
\hline \multicolumn{4}{|l|}{ MELASTOMATACEAE } \\
\hline Tibouchina hospita Cogn. & $\mathrm{Ph}$ & $\mathrm{SE}+\mathrm{S}, \mathrm{R}$ & Brade (1956) \\
\hline Leandra sulfurea (Naud.) Cogn. & $\mathrm{Ph}$ & SE, R & Brade (1956) \\
\hline Chaetostoma glaziovii Cogn. & $\mathrm{Ch}$ & SE, R * & \\
\hline Tibouchina sp. & $\mathrm{Ph}$ & & \\
\hline Melastomataceae sp. 1 & $\mathrm{Ph}$ & & \\
\hline Melastomataceae sp. 2 & $\mathrm{Ph}$ & & \\
\hline \multicolumn{4}{|l|}{ MYRSINACEAE } \\
\hline Myrsine gardneriana A. DC. & $\mathrm{Ph}$ & $\mathrm{SE}+\mathrm{S}, \mathrm{R} *$ & \\
\hline \multicolumn{4}{|l|}{ MYRTACEAE } \\
\hline Myrtaceae sp. 1 & $\mathrm{Ph}$ & & \\
\hline Myrtaceae sp. 2 & $\mathrm{Ph}$ & & \\
\hline \multicolumn{4}{|l|}{ ONAGRACEAE } \\
\hline Fuchsia regia (Vell.) Munz subsp. regia & $\mathrm{Ch}$ & SE, $\mathrm{R}$ & Grillo \& Giulietti (1998) \\
\hline
\end{tabular}


continuation

\begin{tabular}{|c|c|c|c|}
\hline Families / Species & Life-form & Geogr. distribution & Source \\
\hline \multicolumn{4}{|l|}{ ORCHIDACEAE } \\
\hline Prescottia montana Barb. Rodr. & $\mathrm{G}$ & $\mathrm{SE}, \mathrm{R} *$ & \\
\hline Habenaria rolfeana Schltr. & G & $\mathrm{SE}, \mathrm{R} *$ & \\
\hline Pelexia itatiayae Schltr. & $\mathrm{G}$ & $\mathrm{SE}, \mathrm{R} *$ & \\
\hline Habenaria parviflora Lindl. & G & $\mathrm{SE}^{*}$ & \\
\hline \multicolumn{4}{|l|}{ OXALIDACEAE } \\
\hline Oxalis rupestris A. St.-Hil. & G & $\mathrm{SE}+\mathrm{S}, \mathrm{R}$ & Lourteig (1983) \\
\hline \multicolumn{4}{|l|}{ PIPERACEAE } \\
\hline Peperomia galioides Kunth & $\mathrm{Ch}$ & $\mathrm{C}$ & Yuncker (1974) \\
\hline $\begin{array}{l}\text { PLANTAGINACEAE } \\
\text { Plantago } \mathrm{sp} .\end{array}$ & Hros & & \\
\hline \multicolumn{4}{|l|}{ POACEAE } \\
\hline Chusquea heterophylla Nees & Bambu & SE, R & Clark (1992) \\
\hline Chusquea microphylla (Döll) L. G. Clark & Bambu & $\mathrm{E}$ & Clark (1992) \\
\hline Agrostis longiberbis Hackel & $\mathrm{T}$ & $\mathrm{SE}+\mathrm{S}, \mathrm{R}$ & Smith et al. (1982) \\
\hline Agrostis aff. lenis B. R. Arill. \& Izag. & $\mathrm{H}$ & & \\
\hline Agrostis lenis B. R. Arill. \& Izag. & $\mathrm{H}$ & $\mathrm{SE}+\mathrm{S}$ & Longhi-Wagner (2001) \\
\hline Andropogon macrothryx Trin. & $\mathrm{H}$ & $\mathrm{SE}+\mathrm{CB} /$ cone $\mathrm{S}$ & Longhi-Wagner (2001) \\
\hline Axonopus siccus (Nees) Kuhlm. & $\mathrm{H}$ & $\mathrm{SE} /$ cone $\mathrm{S}$ & Longhi-Wagner (2001) \\
\hline Briza calotheca (Trin.) Hack. & $\mathrm{H}$ & $\mathrm{SE}+\mathrm{CB} /$ cone $\mathrm{S}$ & Longhi-Wagner (2001) \\
\hline Briza itatiaiae Ekman & $\mathrm{H}$ & $\mathrm{E}$ & Longhi-Wagner (2001) \\
\hline Cortaderia modesta (Döll) Hack. ex Dusén & $\mathrm{H}$ & $\mathrm{SE}, \mathrm{R} *$ & \\
\hline Danthonia montana Döll & $\mathrm{H}$ & $\mathrm{SE}+\mathrm{S}, \mathrm{R}$ & Longhi-Wagner (2001) \\
\hline Danthonia sp. & $\mathrm{H}$ & & \\
\hline Panicum sp. & $\mathrm{H}$ & & \\
\hline Paspalum polyphyllum Nees ex Trin. & $\mathrm{H}$ & $\mathrm{SE}+\mathrm{CB}+$ cone $\mathrm{S}$ & Longhi-Wagner (2001) \\
\hline Poaceae sp. 1 & $\mathrm{H}$ & & \\
\hline Poaceae sp. 2 & $\mathrm{H}$ & & \\
\hline Poaceae sp. 3 & $\mathrm{H}$ & & \\
\hline \multicolumn{4}{|l|}{ POLYGALACEAE } \\
\hline Polygala campestris Gardner & $\mathrm{Ch}$ & $\mathrm{SE}+\mathrm{S}$ & Marques \& Martins (1997) \\
\hline Polygala pulchella A. St.-Hil. \& Moq. & $\mathrm{Ch}$ & $\mathrm{SE}+\mathrm{S}, \mathrm{R}$ & Marques (1988) \\
\hline \multicolumn{4}{|l|}{ POLYGONACEAE } \\
\hline Rumex acetosella L. & $\mathrm{T}$ & $\mathrm{C}, \mathrm{R}$ & Brandbyge (1989) \\
\hline \multicolumn{4}{|l|}{ PROTEACEAE } \\
\hline Roupala impressiuscula Mez & $\mathrm{Ph}$ & $\mathrm{SE}, \mathrm{R} *$ & \\
\hline \multicolumn{4}{|l|}{ ROSACEAE } \\
\hline Prunus sp. & $\mathrm{Ph}$ & & \\
\hline \multicolumn{4}{|l|}{ RUBIACEAE } \\
\hline $\begin{array}{l}\text { Relbunium indecorum (Cham. \& Schltdl.) } \\
\text { Ehrend. }\end{array}$ & $\mathrm{Ch}$ & A, R & Gomes (1996) \\
\hline Relbunium hypocarpium (L.) Humsl. & $\mathrm{Ch}$ & $\mathrm{SE}+\mathrm{CB} *$ & \\
\hline Coccocypselum lyman-smithii Standley & $\mathrm{Ch}$ & $\mathrm{B}, \mathrm{R} *$ & \\
\hline Rubiaceae sp. 1 & $\mathrm{Ch}$ & & \\
\hline \multicolumn{4}{|l|}{ SAXIFRAGACEAE } \\
\hline Escallonia sp. & $\mathrm{Ph}$ & & \\
\hline \multicolumn{4}{|l|}{ SCROPHULARIACEAE } \\
\hline Esterhazya eitenorum Barringer & $\mathrm{Ph}$ & SE, R & Moura \& Alves (1999) \\
\hline
\end{tabular}


continuation

\begin{tabular}{|c|c|c|c|}
\hline Families / Species & Life-form & Geogr. distribution & Source \\
\hline $\begin{array}{l}\text { SOLANACEAE } \\
\text { Solanum cf. macronotum Bitt. }\end{array}$ & G & $A^{\$}$ & Edmonds (1972) \\
\hline $\begin{array}{l}\text { SYMPLOCACEAE } \\
\text { Symplocos itatiaiae Wawra }\end{array}$ & $\mathrm{Ph}$ & $\mathrm{SE}+\mathrm{S}, \mathrm{R}$ & Occhioni (1975) \\
\hline $\begin{array}{l}\text { VELLOZIACEAE } \\
\text { Pleurostima gounelleana (Beauv.) Men. }\end{array}$ & Hros & E & Smith \& Ayensu (1976) \\
\hline $\begin{array}{l}\text { VIOLACEAE } \\
\text { Viola uleana } \mathrm{W} \text {. Becker }\end{array}$ & $\mathrm{Ch}$ & E & Brade (1956) \\
\hline $\begin{array}{l}\text { XYRIDACEAE } \\
\text { Xyris fusca Nilsson } \\
\text { Xyris wawrae Heimerl }\end{array}$ & $\begin{array}{l}\mathrm{H} \\
\mathrm{H}\end{array}$ & $\begin{array}{l}\text { SE, R } \\
\text { E }\end{array}$ & $\begin{array}{l}\text { Brade (1956) } \\
\text { Brade (1956) }\end{array}$ \\
\hline $\begin{array}{l}\text { SPECIES NOT IDENTIFIED } \\
\text { Not identified } 1 \\
\text { Not identified } 2 \\
\text { Not identified } 3 \\
\text { Not identified } 4\end{array}$ & $\begin{array}{l}\mathrm{Ch} \\
\mathrm{Ph} \\
\mathrm{Ph} \\
\mathrm{Ph}\end{array}$ & & \\
\hline
\end{tabular}

\section{PTERIDOPHYTES}

\begin{tabular}{|c|c|c|c|}
\hline $\begin{array}{l}\text { ASPLENIACEAE } \\
\text { Asplenium serra Langsd. \& Fisch }\end{array}$ & $\mathrm{H}$ & A & Sylvestre (2001) \\
\hline $\begin{array}{l}\text { DRYOPTERIDACEAE } \\
\text { Elaphoglossum gayanum (Fée) T. Moore }\end{array}$ & $\mathrm{H}$ & $\mathrm{A}, \mathrm{R}^{(\$)}$ & Brade (1956) \\
\hline $\begin{array}{l}\text { GRAMMITIDACEAE } \\
\text { Melpomene sp. }\end{array}$ & $\mathrm{H}$ & & \\
\hline $\begin{array}{l}\text { POLYPODIACEAE } \\
\text { Polypodium catharinae Langsd. \& Fisch } \\
\text { Polypodium pleopeltidis Fée } \\
\text { Polypodium hirsutissimum Raddi }\end{array}$ & $\begin{array}{l}\mathrm{H} \\
\mathrm{H} \\
\mathrm{H}\end{array}$ & $\begin{array}{c}\mathrm{A} \\
\mathrm{SE}+\mathrm{S}+\mathrm{CB} \\
\mathrm{SE}+\mathrm{S}+\text { Cone } \mathrm{S}\end{array}$ & $\begin{array}{l}\text { Hensen (1990) } \\
\text { Sehnem (1970) } \\
\text { Sehnem (1970) }\end{array}$ \\
\hline $\begin{array}{l}\text { PTERIDACEAE } \\
\text { Doryopteris itatiaiensis (Fée) Christ } \\
\text { Doryopteris feei Brade }\end{array}$ & $\begin{array}{l}\mathrm{H} \\
\mathrm{H}\end{array}$ & $\begin{array}{l}\text { SE, R } \\
\text { E }\end{array}$ & $\begin{array}{l}\text { Sehnem (1972) } \\
\text { Sylvestre (1995) }\end{array}$ \\
\hline $\begin{array}{l}\text { SELAGINELACEAE } \\
\text { Selaginella tenuissima Fée }\end{array}$ & $\mathrm{Ch}$ & $\mathrm{SE}+\mathrm{S}, \mathrm{R}$ & Brade (1956) \\
\hline
\end{tabular}

* Geographic distributions described directly from herbaria surveys.

\section{Results and discussion}

Species richness - In a discontinuous sample area of 0.034 ha, we found 114 species of vascular plants - of which nine were ferns - belonging to 47 families (table 1). This is more than $25 \%$ of the total of species reported for the whole plateau $(n=415)$ by Martinelli et al. (1989), and reveals the importance of these rock surfaces for overall diversity. All but one species (Solanum aff. macrotonum) had already been registered for the plateau, mainly by Brade (1956). This Solanum is a new species or a new disjunction "Andes-Itatiaia", still to be confirmed
(L. Freire unpublished data). The fact that in our small sampling area we found a large proportion of known species suggests that accounts of species richness for the entire plateau ranging from ca. 400-500 species (Martinelli et al. 1989) are probably underestimates, which might result from the fact that the Prateleiras microregion is the most intensely studied in the plateau. Alternatively, it may also mean that the Prateleiras, due to the high diversity of habitat types it comprises, might indeed maintain in its vegetation islands a considerable proportion of the species found in the whole region. 
Revista Brasil. Bot., V.30, n.4, p.623-639, out.-dez. 2007

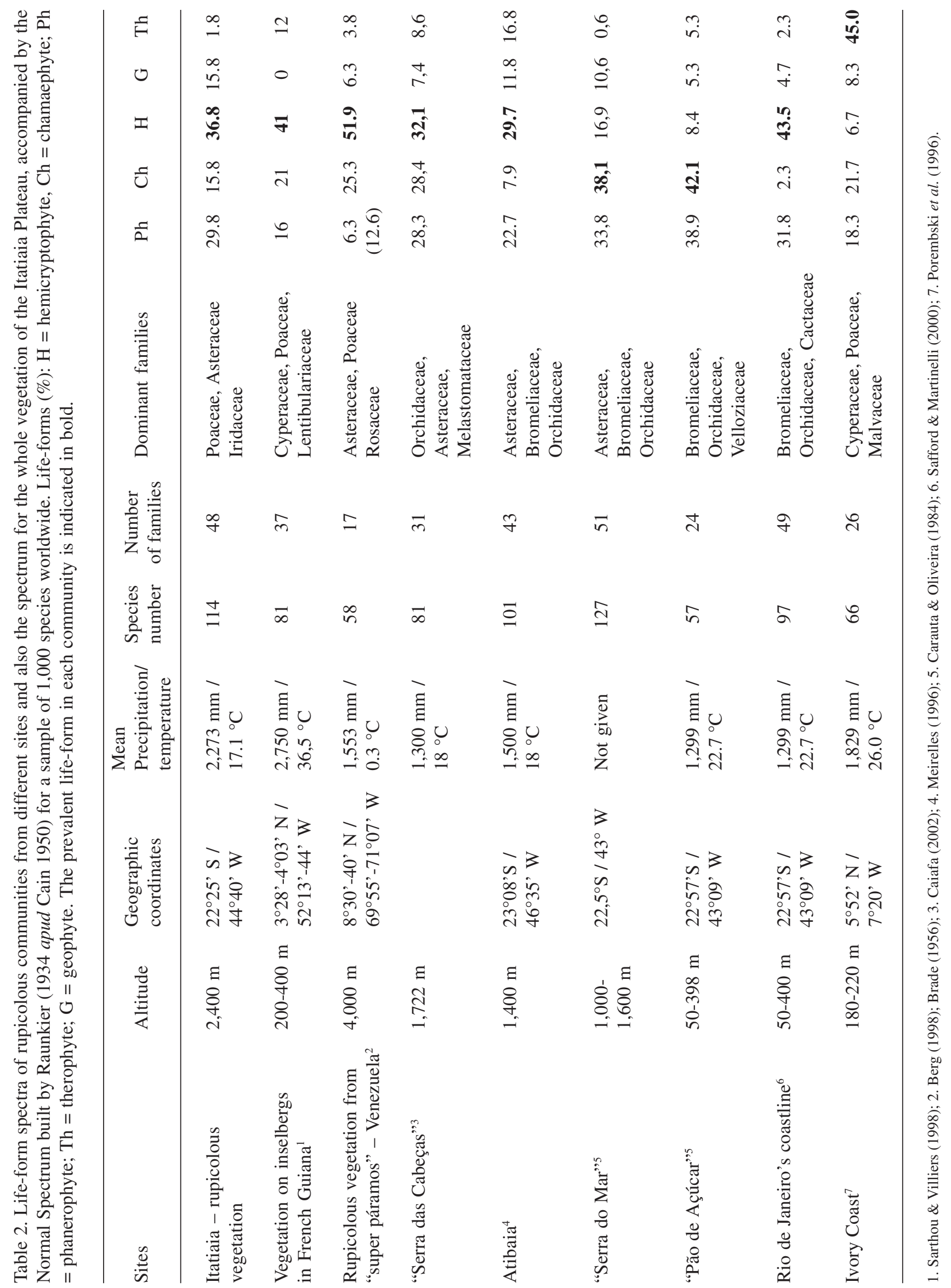


Oettli (1904, apud Larson et al. 2000) observed that on rocks, many distinct habitats can occur close together and/or in mosaic, so that, e.g., marsh plants may grow next to desiccation-tolerant plants. This is also true for Itatiaia. Vegetation islands dominated by Pleurostima gounelleana or Fernseea itatiaiae, plants with xerophytic morphological and physiological traits (Scarano et al. 2001), were often neighbours of wetland plants such as Juncus microcephalus, Xyris teres and Utricularia reniformis, or of mesic woody plants like Baccharis stylosa and Eupatorium alpestre. This spatial heterogeneity explains the high diversity and the high proportion of species on the plateau that are able to establish on rocks. However, there was a clear repetition of species associations that were related to microhabitat variation. For example, $P$. gounelleana was often associated with the moss Campylopus pilifer, each one occurring in more than $50 \%$ of the vegetation islands on exposed rock outcrops, in any microtopography (figure 9). Nevertheless, these species were nearly absent from the talus slope area, where the tank bromeliad Vriesea itatiaiae was common (figure 9). Locally high diversity and the repetition of communities/associations on a broader spatial scale is a common trend on mountain slopes and peaks (Escudero 1996, Alves 2000, Larson et al. 2000, but see Porembski et al. 1998).

Three moss species were particularly abundant and seemed to play an important ecological role in the formation and expansion of vegetation islands on rocks: Campylopus pilifer, Polytrichum commune and Hedwidgium integrifolium (figure 4). The latter grows mainly in water flushes, and $C$. pilifer is a pantropical pioneer species occupying mainly poorly drained sites in "Itatiaia". Other moss species occurred on rocks but at lower densities and played a less clear role in rupicolous vegetation dynamics. More than a hundred moss species have been described for the plateau as a whole (D.P. Costa unpublished data.).

The dominant families of vascular plants were Poaceae and Asteraceae (14.9\% and $10.5 \%$ of the species total, respectively), followed by Melastomataceae, Cyperaceae, Orchidaceae and Rubiaceae (table 1). This pattern conforms to the grasslands in general, but is in clear contrast with data from other rock outcrops in southeastern Brazil at lower elevations, where Orchidaceae and Bromeliaceae are often among the most species-rich families (table 1). Legume species are dramatically reduced in richness and abundance in the high altitude grasslands: only nine species are reported, of which five are Lupinus, a genus associated with temperate climates (Brade 1956). This is relevant, since Fabaceae is a dominant family in many other rock outcrops (Seine et al. 2000), as well as in the adjacent Atlantic forest (Oliveira Filho \& Fontes 2000).

Some other absences are noteworthy, such as species from the genera Epidendrum, Laelia and Pleurothallis (Orchidaceae), Tillandsia and Dickya (Bromeliaceae), Trilepsis (Cyperaceae), Cereus and Rhipsalis (Cactaceae), that are highly diversified and abundant in most other surveyed sites within the Atlantic forest domain (Safford \& Martinelli 2000, Caiafa 2002). Nevertheless, all these genera were found in Pedra Branca (K.T. Ribeiro unpublished data), a syenite rock outcrop $170 \mathrm{~km}$ from Itatiaia, in the municipality of Caldas (Minas Gerais State), which reaches $1,850 \mathrm{~m}$. a.s.l.. At this site the dominant species in Itatiaia were absent - for example, the narrow endemics $P$. gounelleana and F. itatiaiae, showing the effects of climate upon rocky type. Among available studies, the most useful for comparison with Itatiaia due to altitude is the survey of Caiafa (2002) in the "Serra das Cabeças", also part of the "Serra da Mantiqueira" (Municipality of Viçosa, MG), a mountain top at $1,722 \mathrm{~m}$ a.s.l covered with grasslands and rupicolous mats, $270 \mathrm{~km}$ from "Itatiaia". Just six species were common to both sites, and the profile of dominant families and genera was also very different. Further, in the "Serra das Cabeças" the dominant species were Pleurothallis teres and Trilepsis lhotzkiana, which represent genera absent from "Itatiaia", as already mentioned. This may be explained in part due to the effects of distance upon the differentiation of the rupicolous flora, as clearly stated by Seine et al. (2000), who proposed that comparisons between rupicolous florulae should be made at higher taxonomic levels. Another aspect is, however, the unequivocal influence of the temperate climate on the vegetation profile of Itatiaia.

We avoided comparisons of richness with other studies, since these variables are strongly affected by sampling effort (both in time and space), by the criteria used for including each habitat type in the analyses, and by the structure of the habitat, including species area relationships and the sucessional stage of each island, according to size and age. There is still a large avenue for discussion about standardizing sampling methods in rupicolous vegetation in order to allow adequate comparisons. Geographic distribution patterns - The distribution patterns of the rupicolous species we sampled also pointed to the isolation of this vegetation in relation to the adjacent tropical rain forest. There were no species with a generalized distribution in the neighbouring Atlantic forest, unlike other ecosystems found adjacent to the rainforest, such as "restingas" (Araujo et al. 1998, Scarano 2002). More widespread distribution patterns 


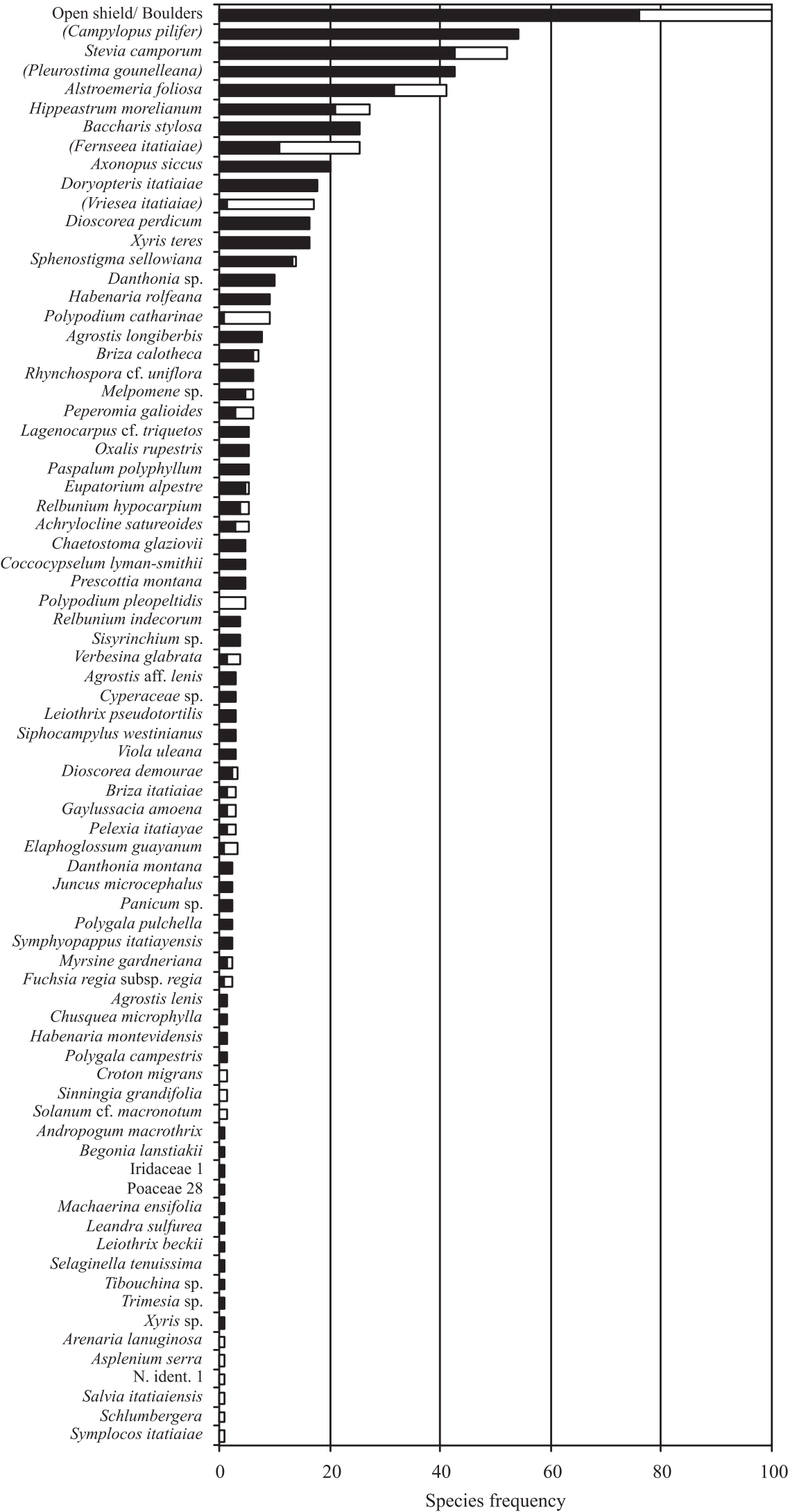

Figure 9. Ranked frequency of species in the rupicolous vegetation islands in Itatiaia. The frequency of each species in islands from the open shields is represented by solid bars and frequency in islands from the boulder area is represented by open bars. The first column indicate the proportion of islands sampled in each habitat. Brackets indicate the mat-forming species. 
are reported for the ruderal Gamochaeta pensylvanica, for the rupicolous or epiphytic Piperaceae Peperomia galioides, and the temperate or tropical montane Rumex acetosella (a cosmopolitan species); and for eight species widely distributed in high and/or temperate localities in the Americas (table 1). A high proportion of the species found were restricted to southeastern Brazil or to southeastern and southern Brazil $(n=63,72.4 \%)$. Of this group, 13 were narrow endemics, found only on the Itatiaia plateau and on the peaks of some adjacent mountain chains ("Serra Negra", "Serra Fina" and "Pico do Itaguaré"; see Brade 1956); 26 species were restricted to the southeastern mountains in general ("Serra da Mantiqueira" and "Cadeia do Espinhaço"); and 19 occurred also in decreasing altitudes towards southern Brazil. The rupicolous vegetation sampled showed a higher proportion of endemics than the flora of the plateau as a whole $(14.4 \%$ vs. $11 \%)$, from which two were nearly confined to the rock surfaces - Fernseea itatiaiae and Pleurostima gounelleana. These two species and the montane Vriesea itatiaiae were dominant in the landscape, and were responsible for the formation and/or expansion of most vegetation mats (figures 1-9). Additionally, they all belong to typically tropical families with low species richness in cold places (Smith \& Downs 1979).

Almost all grasses occurring in the study area (e.g., Chusquea-Bambuseae, Cortaderia - Arundinae, Agrostis - Agrosteae, and Danthonia-Danthonieae) are mesothermic, according to Burkart (1975), since they occur only in mild temperate climates (mean temperatures: 10 to $20{ }^{\circ} \mathrm{C}$ ), unlike megathermic (means over $20^{\circ} \mathrm{C}$ ) and microthermic (below $10{ }^{\circ} \mathrm{C}$ ) grasses. In the Andes, at correspondent latitudes, mesothermic conditions occur from 1,500 to 3,500 $\mathrm{m}$ a.s.l., and in Brazil, between $28^{\circ}$ and $40^{\circ}$ latitude S (Burkart 1975), and at decreasing altitudes southward.

The characteristics of a temperate climate are also suggested when photosynthetic mechanisms are considered. Although very common in rocky surfaces at lower elevations, CAM (crassulacean acid metabolism) plants are nearly absent in Itatiaia (Scarano et al. 2001). For example, the bromeliad Nidularium itatiaiae was one of few CAM species, as detected by ${ }^{13} \mathrm{C}$ discrimination analysis (carbon isotope ratio) of leaf tissues, and was found in places protected from the wind and temperature extremes, which are possibly places where nocturnal stomata opening is possible. The other bromeliad, Fernseea itatiaiae, a narrow endemic but common in a large range of habitat types on the plateau, showed all the characteristics of $\mathrm{C}_{3}$ metabolism (Scarano et al. 2001). The authors remark that this species belongs to a sub-family (Bromelioideae) where all other species have been reported as CAM.
The cactus Schlumbergera obtusangula also demonstrated $\mathrm{C}_{3}$ behaviour, which is another curious exception since its family is almost entirely CAM. The prevalence of the $\mathrm{C}_{3}$ pathway on the Itatiaia Plateau may reflect the very low nocturnal temperatures. However, since other other high altitude zones in South America have CAM plants (Medina \& Delgado 1976, Keeley \& Keeley 1989), the shortage of CAM species in this vegetation deserves further investigation.

Life forms - Understanding why rupicolous vegetation from different places can show such different life-form spectra is a difficult task since two factors have strong effects upon the plants - the climate itself, which originated the rationale supporting the proposition of life-forms by Raunkiaer (the phytoclimates; Cain 1950) and the edaphic conditions, in that differences in substrate, topography and drainage can completely change the dominance of contrasting life-forms.

The distribution of life forms in the rupicolous vegetation was in harmony with the local characteristics of temperate climate (Cain 1950). There was a predominance of hemicryptophytes, which were either graminoids (32 species) or rosettes ( 10 species), and belonged to various families (table 1). The dominance of this life form was also observed in five other studies on rupicolous vegetations (see table 2). There were also many phanerophytes, mostly small-sized, due probably to wind action (figure 8). In areas protected by boulders, shrubs and trees may reach heights of 3-4 m. Cain (1950) showed a trend of increasing proportions of chamaephytes with elevation, accompanied by an increasing proportion of hemicryptophytes on many mountain slopes. Pavón et al. (2000) also found the same pattern for chamaephytes, but the opposite for cacti and phanerophytes in a semiarid valley in Mexico. Among those studies about rupicolous vegetation within the Atlantic forest domain, no obvious pattern is readily apparent (table 2).

In the "Serra Fina", a mountain massif just $20 \mathrm{~km}$ far from the "Itatiaia" massif and at the same average altitude, the rock surface covered with fissures and cracks harboured a much larger proportion of phanerophytes (B.M.O. Medina, unpublished data) than the prevalent convex surface of Itatiaia, where hemicryptophytes are able to grow forming mats. In our Itatiaia site, phanerophytes were under-represented in part due to scarcity of cracks. Further, differences in sampling methods and in criteria for inclusion of each one of the many vegetation types found on rock outcrops (from monocot mats to thickets on deeper soils) may result in larger or lesser inclusion of phanerophytes.

Cryptophytes were an important component of rupicolous vegetation in Itatiaia, as already indicated by 
Brade (1956). We found 18 species (15.8\% of the total), mostly geophytes, a similar proportion found in the rupicolous flora of Atibaia (state of São Paulo), at 1,600 $m$ a.s.l. (11.8\%; Meirelles 1996). Caiafa (2002), in "Serra do Brigadeiro" (state of Minas Gerais), found just 8.6\% geophytes in rupicolous vegetation patches. In a rock outcrop in the "superpáramos" (Sierra Nevada, Venezuela, elevation ca. $4,000 \mathrm{~m}$ ), geophytes were only $0.04 \%$ of the flora (Berg 1998) and in inselbergs in French Guiana they were completely absent (Sarthou \& Villiers 1998).

The relative abundance of this life form in Atibaia and Itatiaia, as opposed to its scarcity in the "superpáramos" or absence in equatorial inselbergs, may result from the marked seasonality of temperature and humidity in the Brazilian sites. The "páramos", conversely, have almost constant monthly mean temperatures and near $0{ }^{\circ} \mathrm{C}$ temperatures almost every night. Thus, in the latter, and mainly in the colder "superpáramos", the investment in underground reserves may be less favoured than strategies that allow for shoot maintenance throughout the year, such as in the case of caulescent rosette plants, cushion plants (Monasterio 1986, Berg 1998) or even small phanerophytes (Sarthou \& Villiers 1998).

The low proportion of therophytes in Itatiaia $(1.8 \%)$ and in many nearby sites deserves further investigation, as stated by Safford \& Martinelli (2000), mainly if compared with data from Taï forest in Ivory Coast, West Africa, where Porembski et al. (1996) found $45 \%$ of therophytes (table 2). Therophytes may be rare on Itatiaia rocks due to a combination of short growing seasons and low nutrient budgets on rock surfaces (Larson et al. 2000, Benites et al. 2003) that preclude rapid establishment and growth. Low temperatures alone do not explain the absence of therophytes in Itatiaia, since this life strategy is very common in many temperate regions (Cain 1950). This is reinforced by the observation that after an extensive wildfire in July 2001, many therophytes like Gamochaeta pennsylvanica and Rumex acetosella established and flowered in large numbers, even in unburnt islands (Ribeiro 2002). This was possibly due to an input of usually limiting nutrients, mainly phosphorous, triggering the germination, establishment and growth of these ruderal species (Whelan 1995, Enright et al. 1997, Verboom et al. 2002). This pattern is paralelled by Yates et al. (2003), who showed that in a frequently burnt rock outcrop in Australia, most species were therophytes (45\%) and only $7 \%$ were geophytes. Vegetation structure - Some characteristics of the dominant rock in Itatiaia - the nepheline-syenite - seem to also have a role in the promotion of plant diversity. The erosion by dissolution creates many holes and shallow depressions with variable flooding regimes.
Additionally, the scarcity of cracks and fissures favours the establishment of mat-forming species, mainly rosetted hemicryptophytes, upon which a large array of other species may establish. Vegetation islands seem to correspond to different sucessional stages, according in part to their area, as suggested by a strong species-area relationship, where the slope coefficient is above 0.30 in the logarithmic space (Ribeiro 2002). Small islands bear a few (usually 2 to 4) species, many of them specialized rupicolous plants, either epilithic or saxicolous. But high species richness is associated with this group of small islands, since the composition of low abundance species associated with the mat forming plants is highly variable and sorted from a large pool of species.

Nearly all islands are dominated by hemicryptophytes, such as bromeliads or Velloziaceae, and sometimes ferns like Doryopteris itatiaiae and mosses, with the periodic appearance of graminoids and cryptophytes. These species provide different establishment conditions for other plants, according to their growth forms and to microhabitat conditions where each different species prevails (Ribeiro 2002, Medina et al. 2006).

There is a clear segregation in species composition between the two habitats - the rock shields and the tallus slope (figure 9). Campylopus pilifer, Pleurostima gounelleana and Baccharis stylosa, frequent in the rock shield, were absent from the talus slope, whereas Vriesea itatiaiae has just two individuals in the former, but was found in $15.5 \%$ of the islands of the latter. The geophytes Stevia camporum, Alstroemeria foliosa and Hippeastrum morelianum and the bromeliad Fernseea itatiaiae were the most widespread species, found in high frequencies in all microhabitat types (present in $51.9 \% ; 41.1 \% ; 27.1 \%$ and $25.6 \%$ of the total group of islands, respectively).

On the rock shields there was a large number of rocky pools, most of them devoid of vascular species (figure 7). Islands with a horseshoe shape were common in pools flooded for a longer time, since pioneer species occupy only their borders, avoiding flooding (figure 4). Conversely, the steep surfaces at these exposed sites were rarely occupied by vascular plants or even mosses, due to humidity deficit and lack of fissures. More islands were found in flatter areas, associated with depressions and under contrasting drainage regimes. Depending on the relative position of a given depression in the landscape, it may continuously receive a large amount of water drained from neighbouring vegetation or, conversely, be dry most of the time, supporting very different species.

A different picture was found along the boulders at the talus slope. These boulders are more protected from 
wind and direct sunlight, and the islands formed on them do not receive any water drained from upper sites. So, they represent more mesic and homogeneous places, in contrast with the rocky shield, where plants may be flooded and/or highly desiccated. In the main vegetated microhabitat types there were smooth surfaces of variable inclinations and shallow deppressions. Species that preferably occupy each of such topographies are listed in Ribeiro \& Medina (2002).

Since there was a direct relationship between island area and species richness in this system (Ribeiro 2002) and in similar cases (Michelangeli 2000), it is relevant to ask which are the limits for increase in island size. In Itatiaia, plants are often confined to concavities (figures $3,4,6$ ), and most of the vegetation on exposed places show high patchiness, associated either with well-drained shallow depressions or rock pools. This is probably caused by a combination of harsh climatic conditions (strong winds, dryness and freezing temperatures) and the scarcity of safe sites for seed establishment (see Jumpponen et al. 1999), namely lack of soil and associated nutrients and available water. The only exceptions are the steep and smooth surfaces of protected boulders where $V$. itatiaiae clumps are abundant. There, the plumate seeds of this species are able to adhere to the rock surface in these constantly humid places, together with many moss species. But the weight of these tank-forming bromeliads may impair the continuous growth of the clumps in very steep surfaces.

In Itatiaia, the very smooth rock surfaces and the desiccating wind impair plant establishment. The amount of water that a rocky surface may hold is proportional to its fracturing pattern and to the size of the crystals (Larson et al. 2000). The limitations to growth may hinder fusion between islands and the successional process. Islands are often poorly attached to the rocks, given the scarcity of fissures and large crystals, and therefore many are uprooted by extreme weather, or trampled by tourists and livestock. Thus, even extensive flat surfaces are occupied by small islands, and fusion between these islands is rare.

Final remarks - High altitude tropical ecosystems occurring near the ecuatorian line, within ca. $11^{\circ} \mathrm{N}$ and $8^{\circ} \mathrm{S}$, have been collectively named "páramos" - a term originated in Peru, Venezuela and Colombia - in various studies (e.g., Lauer 1981, Rundel 1994, Hofstede et al. 2003). We argue that Safford's (1999 a, b) use of the expression "Brazilian páramos", in reference to Brazilian high altitudinal grasslands or "campos de altitude", should be seen with caution, although we agree that establishing broad taxonomic categories for vegetation types is a necessary step toward the understanding of continental or worldwide biogeographic patterns. From the several factors discussed in this paper that confer a strong individuality to the "campos de altitude", we highlight the following: (1) exposure to a stronger seasonality as compared to mountain vegetation from north Peru up to Costa Rica; (2) proximity to the species-rich Atlantic rain forest and distance from the Andean region, conferring floristic individuality to the "campos de altitude", despite the presence of some genera and a few species in common with the latter.

Irrespective of this terminological debate, it is clear that the rupicolous vegetation is of exceptional importance to the ecological and botanical diversity of the Itatiaia Plateau. The sensitivity of this vegetation to disturbance such as trampling (by both livestock and tourists) and fire demands special attention regarding its protection (Ribeiro et al. 2004). This is particularly necessary in the face of increasing pressure on "Itatiaia" by those practicing outdoor recreation (Tierney 2002).

Acknowledgements - We thank Léo Nascimento and his staff at "Parque Nacional do Itatiaia" (Ibama) for accomodation facilities and support; Brazilian Research (CNPq) and Graduate Education Councils (Capes) for research grants to all authors; Fundação Botânica Margaret Mee for a fellowship to KTR that supported her work in Kew Botanical Gardens (UK); and Pronex-Finep (0877) for funding. We are particularly thankful to the specialists who identified most of the botanical material (Daniela Zappi (K), Elsie Guimarães (RB), Gilberto Pedralli (Cetec), Henrik Balslev (AAU), Hilda Longhi-Wagner (UFRGS), João Marcelo Braga (RB), José Baumgratz (RB), Julie Dutilh (Unicamp), Lana Sylvestre (RB), Lúcia Freire (RB), Maria das Graças Wanderley (IB), Maria de Fátima Freitas (USP), Ana Maria Giulietti (UFFS), Paulo Labiak (UFPR), Roberto Esteves (R), Ruy Alves (R) e Tânia Wendt (SFA).

\section{References}

ALMEIDA, F.F.M. 1961. Geologia e petrologia da Ilha de Trindade. Monograph 18. Departamento Nacional de Pesquisas Minerológicas, Rio de Janeiro.

ALVES, R.J.V. 2000. Primary succession on quartzite cliffs in Minas Gerais, Brazil. Biologia, Bratislava 55:69-83.

ARAUJO, D.S.D., SCARANO, F.R., SÁ, C.F.C., KURTZ, B.C., ZALUAR, H.L.T., MONTEZUMA, R.C. \& OLIVEIRA, R.C. 1998. As comunidades vegetais do Parque Nacional da Restinga de Jurubatiba. In Ecologia das lagoas costeiras do Parque Nacional da Restinga de Jurubatiba e do Município de Macaé (F.A. Esteves, ed.). Núcleo de Pesquisas Ecológicas de Macaé/Universidade Federal do Rio de Janeiro, Rio de Janeiro, p.34-63. 
ASSIS, M.C. 2004. Alstroemeriaceae no estado do Rio de Janeiro. Rodriguésia 55:5-15.

BALSLEV, H. 1996. Juncaceae. Flora Neotropica Monograph 68:106-109.

BARROSO, G.M. 1957. Flora do Itatiaia I: Compositae. Rodriguésia 32:175-241.

BENITES, V.M., CAIAFA, A.N., MENDONÇA, E.S., SCHAEFER, C.E. \& KER, J.C. 2003. Solos e vegetação nos complexos rupestres de altitude da Mantiqueira e do Espinhaço. Floresta e Ambiente 10:76-85.

BENZING, D.H. 2000. Bromeliaceae: profile of an adaptive radiation. Cambridge University Press, Cambridge.

BERG, A.L. 1998. Pflanzengesellschaften und Lebensformen des Superpáramo des Parque Nacional Sierra Nevada de Mérida in Venezuela. Phytocoenologia 28:157-203.

BOOTH, B.D. \& LARSON, D.W. 1999. Impact of language, history, and choice of system on the study of assembly rules. In Ecological assembly rules: Perspectives, advances, retreats (E. Weiher \& P. Keddy, eds.). Cambridge University Press, Cambridge, p.206-229.

BRADE, A.C. 1956. A flora do Parque Nacional do Itatiaia. Boletim do Parque Nacional do Itatiaia 5:1-114.

BRADE, A.C. 1959-1961. O porte das begônias brasileiras e os ambientes onde ocorrem. Arquivos do Jardim Botânico do Rio de Janeiro 17:51-55.

BRANDBYGE, J. 1989. Polygonaceae. Flora of Ecuador 38:1-61.

BURKART, A. 1975. Evolution of grasses and grasslands in South America. Taxon 24:53-66.

BURKE, A. 2002a. Island-matrix relationships in nama Karoo inselberg landscapes Part I: Do inselbergs provide a refuge for matrix species? Plant Ecology 160:79-90.

BURKE, A. 2002b. Island-matrix relationships in nama Karoo inselberg landscapes Part II: Are some inselbergs better sources than others? Plant Ecology 158:41-48.

CABRERA, A.L. \& KLEIN, R.M. 1989. Compostas. In Flora ilustrada catarinense (R. Reitz, ed.). Herbário Barbosa Rodrigues, Itajaí.

CAIAFA, A.N. 2002. Composição florística e estrutura da vegetação sobre um afloramento rochoso no Parque Estadual da Serra do Brigadeiro, MG. Dissertação de mestrado, Universidade Federal de Viçosa, Viçosa.

CAIN, S.A. 1950. Life-forms and phytoclimates. The Botanical Review 16:1-32.

CARAUTA, J.P.P. \& OLIVEIRA, R.R. 1984. Plantas vasculares dos morros da Urca, Pão de Açúcar e Cara de Cão. Rodriguésia 36:13-24.

CLARK, L.G. 1992. Chusquea sect. Swallenochloa (Poaceae: Bambusoideae) and allies in Brazil. Brittonia 44:387422.

CUATRECASAS, J.C. \& SMITH, L.B. 1971. Cunoniáceas. In Flora ilustrada catarinense (R. Reitz, ed.). Herbário Barbosa Rodrigues, Itajaí.

DAUBENMIRE, R. 1968. Ecology of fire in grasslands. Advances in Ecological Researches 5:209-266.
DEBROT, A.O. \& FREITAS, J.A. 1993. A comparison of ungrazed and livestock-grazed rock vegetations in Curaçao. Biotropica 25:270-280.

DUKE, J.A. 1961. Flora of Panama: Caryophyllaceae. Annals of the Missouri Botanical Garden 48:173-268.

EDMONDS, J.M. 1972. A synopsis of the taxonomy of Solanum sect. Solanum (Maurella) in South America. Kew Bulletin 27:95-114.

ENRIGHT, N.J., GOLDBLUM, D., ATA, P. \& ASHTON, D.H. 1997. The independent effects of heat, smoke and ash on emergence of seedlings from soil seed bank of a healthy Eucalyptus woodland in Grampians (Gariwerd) National Park, Western Victoria. Australian Journal of Ecology 22:81-88.

ESCUDERO, A. 1996. Community patterns on exposed cliffs in a Mediterranean calcareous mountain. Vegetatio 125: 99-110.

FREIRE, S.E. 1993. A revision of Chionolaena (Compositae, Gnaphalieae). Annals of the Missouri Botanical Garden 80:397-438

FULLS, E.R., BREDENKAMP, G.J. \& VAN ROOYEN, N. 1993. Low thicket communities of rock outcrops in the northern Orange Free State. South African Journal of Botany 59:360-369.

GOMES, M. 1996. Rubiaceae. In Reserva Ecológica de Macaé de Cima (M.P.M. Lima \& R.R. Guedes-Bruni, eds.), Jardim Botânico do Rio de Janeiro, Rio de Janeiro, v.2, p.345-424.

GRILLO, A.A. \& GIULIETTI, A.M. 1998. Flora da Serra do Cipó, MG: Onagraceae. Boletim de Botânica da Universidade de São Paulo 17:109-114.

HARIDASAN, M. 2000. Nutrição mineral de plantas nativas do cerrado. Revista Brasileira de Fisiologia Vegetal 12: 54-64.

HENSEN, R.V. 1990. Revision of the Polypodium loriceumcomplex (Filicales, Polypodiaceae). Nova Hedwigia 50: 279-336.

HOFSTEDE, R., SAGARRA, P. \& MENA-VÁSCONEZ, P. 2003. Los páramos del mundo. Proyecto Atlas Mundial de los Páramos, 2003. Global Peatland Initiative/NCIUCN/EcoCiencia, Amsterdam.

HOULE, G. \& PHILLIPS, D.L. 1989. Seasonal variation and annual fluctuation in granite outcrop communities. Vegetatio 80:25-35.

HUNT, D.R. 1968. Contributions to the flora of tropical America: LXXVII. A synopsis of Schlumbergera Lem. (Cactaceae). Kew Bulletin 23:255-263.

JUMPPONEN, A., VÄRE, H., MATTSON, K.M., OHTONEN, R. \& TRAPPE, J.M. 1999. Characterization of 'safe sites' for pioneers in primary succession on recently deglaciated terrain. Journal of Ecology 87:98-105.

KEELEY, J.E. \& KEELEY, S.C. 1989. Crassulacean acid metabolism (CAM) in high elevation tropical cactus. Plant Cell and Environment 12:331-336.

KREBS, C.J. 1998. Ecological methodology, $2^{\text {nd }}$ ed. Benjamin/ Cummings, Menlo Park. 
LARSON, D.W., MATTHES, U. \& KELLY, P.E. 2000. Cliff ecology: pattern and process in cliff ecosystems. Cambridge Studies in Ecology. Cambridge University Press, Cambridge.

LAUER, W. 1981. Ecoclimatological conditions of the páramo belt within the tropical high mountains. Mountain Research and Development 1:209-221.

LEINZ, V. \& AMARAL, S.E. 1989. Geologia geral. Companhia Editora Nacional, São Paulo.

LONGHI-WAGNER, H. 2001. Poaceae. In Flora fanerogâmica do Estado de São Paulo (M.G.L. Wanderley, G.J. Shepherd \& A.M. Giulietti, coords.). Hucitec, São Paulo, p.1-292.

LOURTEIG, A. 1983. Oxalidáceas. In Flora ilustrada catarinense (R. Reitz, ed.). Herbário Barbosa Rodrigues, Itajaí.

LUTEYN, J.L. 1995. Ericaceae. Flora Neotropica Monograph 66:457-458.

LÜTTGE, U. 1997. Physiological ecology of tropical plants. Springer-Verlag, Berlin.

MAJOR, J. 1988. Endemism, a botanical perspective. In Analytical biogeography: an integrated approach to the study of animal and plant distributions (A.A. Myers \& P.S. Giller, eds). Chapman \& Hall, London, p.117-146.

MARQUES, M.C.M. 1988. Revisão do gênero Polygala L. Arquivos do Jardim Botânico do Rio de Janeiro 29:1-114.

MARQUES, M.C.M. \& MARTINS, M. 1997. Flora do estado do Rio de Janeiro - Polygalaceae. Albertoa 4:130-182.

MARTINELLI, G., BANDEIRA, J. \& BRAGANÇA, J.O. 1989. Campos de Altitude. Index, Rio de Janeiro.

MEDINA, E. \& DELGADO, M. 1976. Photosynthesis and night $\mathrm{CO}_{2}$ fixation in Echeveria columbiana Poellnitz. Photosynthetica 10:155-163.

MEDINA, B.M.O., RIBEIRO, K.T. \& SCARANO, F.R. 2006. Plant-plant and plant-topography interactions on a rock outcrop at high altitude in southeastern Brazil. Biotropica 38:1-7.

MEIRELLES, S.T. 1996. Estrutura da comunidade e características funcionais dos componentes da vegetação de um afloramento rochoso em Atibaia - SP. Tese de doutorado, Universidade Federal de São Carlos, São Carlos.

MEIRELLES, S.T., MATTOS E.A. \& SILVA, A.C. 1997. Potential desiccation tolerant vascular plants from southeastern Brazil. Polish Journal of Environmental Studies 6:17-21.

MICHELANGELI, F.A. 2000. Species composition and species-area relationships in vegetation isolates on summit of a sandstone mountain in southern Venezuela. Journal of Tropical Ecology 16:69-82.

MONASTERIO, M. 1986. Adaptive strategies of Espeletia in the Andean desert páramo. In High altitude tropical biogeography (F. Vuillemier \& M. Monasterio, eds.). Oxford University Press, Oxford, p.47-80.

MONASTERIO, M. \& VUILLEMIER, F. 1986. Introduction: high mountain tropical biota of the world. In High altitude tropical biogeography (F. Vuillemier \& M. Monasterio, eds.). Oxford University Press, Oxford, p.3-7.
MOURA, R.B. \& ALVES, R.J.V. 1999. Uma nova espécie de Esterhazya J.C. Mikan (Scrophulariaceae) do Brasil. Bradea 26:145-148.

OCCHIONI, P. 1975. Symplocaceae do Parque Nacional do Itatiaia. Leandra 5:65-88.

OLIVEIRA FILHO, A.T. \& FONTES, M.A.L. 2000. Patterns of floristic differentiation among Atlantic Forests in Southeastern Brazil, and the influence of climate. Biotropica 32:793-810.

PAVÓN, N.P., HERNANDEZ-TREJO, H. \& RICO-GRAY, V. 2000. Distribution of plant life forms along an altitudinal gradient in the semi-arid valley of Zapotitlan, México. Journal of Vegetation Science 11:39-42.

PEREIRA, E. 1957. Flora do Itatiaia I. Labiatae. Rodriguésia 20:89-104.

POREMBSKI, S., BARTHLOTT, W., DÖRRSTOCK, S. \& BIEDINGER, N. 1994. Vegetation of rock outcrops in Guinea: granite inselbergs, sandstone table mountains and ferricretes - remarks on species numbers and endemism. Flora 189:315-326.

POREMBSKI, S., SZARZYNSKI, J., MUND, J.-P. \& BARTHLOTT, W. 1996. Biodiversity and vegetation of small-sized inselbergs in a West African rain forest (Taï, Ivory Coast). Journal of Biogeography 23:4755.

POREMBSKI, S., MARTINELLI, G., OHLEMULLER, R. \& BARTHLOTT, W. 1998. Diversity and ecology of saxicolous vegetation mats on inselbergs in Brazilian Atlantic forest. Diversity and Distributions 4:107-119.

RIBEIRO, K.T. 2002. Estrutura, dinâmica e biogeografia das ilhas de vegetação rupícola do Planalto do Itatiaia, RJ. Tese de doutorado, Universidade Federal do Rio de Janeiro, Rio de Janeiro.

RIBEIRO, K.T. \& MEDINA, B.M.O. 2002. Estrutura, dinâmica e biogeografia das ilhas de vegetação sobre rocha do Planalto do Itatiaia, RJ. Boletim do Parque Nacional do Itatiaia, 10:1-82.

RIBEIRO, K.T., LORENZETTO, A. \& RODRIGUES, C.G.O. 2004. Bases para o manejo de escaladas em unidades de conservação. Anais do IV Congresso Brasileiro de Unidades de Conservação. Trabalhos técnicos. Fundação O Boticário para a Proteção à Natureza, Curitiba, p.335-345.

RIZZINI, C.T. 1979. Tratado de fitogeografia do Brasil, v.2. Hucitec/Edusp, São Paulo.

ROSENZWEIG, M.L. 1995. Species diversity in space and time. Cambridge University Press, Cambridge.

RUNDEL, P.W. 1994. Tropical alpine climates. In Tropical alpine environments. Plant form and function (P.W. Rundel, A.P. Smith \& F.C Meinzer, eds.). Cambridge University Press, Cambridge, p.21-43.

SAFFORD, H. 1999a. Brazilian Páramos I. An introduction to the physical environment and vegetation of the campos de altitude. Journal of Biogeography 26:693712 . 
SAFFORD, H. 1999b. Brazilian Páramos II. Macro- and mesoclimate of the campos de altitude and affinities with high mountain climates of the tropical Andes and Costa Rica. Journal of Biogeography 26:713-737.

SAFFORD, H. 2001. Brazilian Páramos III. Patterns and rates of postfire regeneration in the campos de altitude. Biotropica 33:282-302.

SAFFORD, H. \& MARTINELLI, G. 2000. Southeast Brazil. In Inselbergs (S. Porembski \& W. Barthlott, eds.). Ecological Studies v.146. Springer-Verlag, Berlin, p. 339-388.

SARTHOU, C. \& VILLIERS, J. 1998. Epilithic plant communities on inselbergs in French Guiana. Journal of Vegetation Science 9:847-860.

SCARANO, F.R. 2002. Structure, function and floristic relationships of plant communities in stressful habitats marginal to the Brazilian Atlantic forest. Annals of Botany 90:517-524.

SCARANO, F.R., DUARTE, H.M., RIBEIRO, K.T., RODRIGUES, P.J.F.P., BARCELLOS, E.M.B., FRANCO, A., BRULFERT, J., DELEÉNS, E. \& LÜTTGE, U. 2001. Four sites of contrasting environmental stress in southeastern Brazil: relations of species, life form diversity, and geographic distribution to ecophysiological parameters. Botanical Journal of the Linnean Society 136:345-364.

SEGADAS-VIANNA, F. \& DAU, L. 1965. Ecology of the Itatiaia range, southeastern Brazil. II - Climates and altitudinal climatic zonation. Arquivos do Museu Nacional 53:31-53.

SEHNEM, A. 1970. Polypodiáceas. In Flora ilustrada catarinense (R. Reitz, ed.). Herbário Barbosa Rodrigues, Itajaí.

SEHNEM, A. 1972. Pteridáceas. In Flora ilustrada catarinense (R. Reitz, ed.). Herbário Barbosa Rodrigues, Itajaí.

SEINE, R., BECKER, U., POREMBSKI, S., FOLLMAN, G. \& BARTHLOTT, W. 1998. Vegetation of inselbergs in Zimbabwe. Edinburgh Journal of Botany 55:267-293.

SEINE, R., POREMBSKI, S. \& BECKER, U. 2000. Phytogeography. In Inselbergs (S. Porembski \& W. Barthlott, eds.). Ecological Studies v.146. Springer-Verlag, Berlin, p.435-449.

SMITH, L.B. \& AYENSU, E.S. 1976. A revision of American Velloziaceae. Smithsonian Contributions to Botany 30:1-172.
SMITH, L.B. \& DOWNS, R.J. 1977. Tillandsioideae (Bromeliaceae). Flora Neotropica Monograph 14:6631492.

SMITH, L.B. \& DOWNS, R.J. 1979. Bromelioideae (Bromeliaceae). Flora Neotropica Monograph 14:14932142.

SMITH, L.B., WASSHAUSEN, D.C. \& KLEIN, R. 1982. Gramíneas. In Flora ilustrada catarinense (R. Reitz, ed.). Herbário Barbosa Rodrigues, Itajaí.

SMITH, L.B., DOWNS, R.J. \& KLEIN, R.M. 1988. Euforbiáceas. In Flora ilustrada catarinense (R. Reitz, ed.). Herbário Barbosa Rodrigues, Itajaí.

SYLVESTRE, L. 1995. Palinologia das Polypodiáceas sensu lato do Planalto do Itatiaia. Arquivos do Jardim Botanico do Rio de Janeiro 33:9-73.

SYLVESTRE, L. 2001. Revisão das espécies da família Aspleniaceae A.B. Frank ocorrentes no Brasil. Tese de doutorado, Universidade de São Paulo, São Paulo.

TAYLOR, P.G. 1980. The genus Utricularia - a taxonomic monograph. Royal Botanic Gardens, Kew.

TIERNEY, P.T. 2002. United States protected natural areas and tourism: a historical perspective. In Unidades de conservação: atualidades e tendências (M.S. Milano, org.). Fundação O Boticário de Proteção à Natureza, Curitiba, p.131-143.

THOMAS, W.M., CARVALHO, A.M.V., AMORIM, A.M., GARRISON, J. \& ARVELAEZ, A.L. 1998. Plant endemism in two forests in southern Bahia, Brazil. Biogeography and Conservation 7:311-322.

TRINTA, E.F. \& SANTOS, E. 1989. Campanuláceas. In Flora ilustrada catarinense (R. Reitz, ed.). Herbário Barbosa Rodrigues, Itajaí.

VERBOOM, G.A., STOCK, W.D. \& LINDER, P. 2002. Determinants of postfire flowering in the geophitic grass Ehrharta capensis. Functional Ecology 16:705713.

WHELAN, R.J. 1995. Fire ecology. Cambridge University Press, Cambridge.

YATES, C.J., HOPPER, S.D., BROWN, A. \& VAN LEEUWEN, S. 2003. Impact of two wildfires on endemic granite outcrop vegetation in Western Australia. Journal of Vegetation Science 14:185-194.

YUNCKER, T.G. 1974. The Piperaceae of Brazil. Hoehnea 4:83-185. 